\title{
From Courtship to “Occasional Prostitution”: Acceptable and Unacceptable Public Displays of Sexuality in Canada from 1880 to 1920
}

Melissa Bauman

In nineteenth century Canada, sexuality was strictly regulated. While sexuality was usually not discussed overtly, it was discussed implicitly by associating it with reputation, character, and morality. As urban centers grew, they became associated with vice, which created anxieties concerning the acceptable public displays of sexual behaviour. Evidence of what I will call an "early dating culture" can be found in the Toronto Social Survey Report that was conducted in the early twentieth century as a result of the changing societal norms. Over a 40 year time span-from 1880 to 1920-drastic changes occurred in what behaviours were considered socially acceptable. Late nineteenth century societal norms were tested by the effects of urbanization; there emerged an early dating culture that challenged notions of morality in relation to acceptable and unacceptable public displays of heterosexuality.

Etiquette manuals from the late nineteenth century stressed the importance of reputation, character, and morality, and linked these to sexuality. Azoulay's study of etiquette manuals and advice columns explains how good character was simultaneously stressed and judged. ${ }^{1}$ A person's character was judged based on their behaviour, and it was important to behave properly so as to distinguish between social classes. Azoulay said "polite society" consisted of "members of the middle and upper classes [who were] eager to distinguish themselves from the 'rougher' classes." 2 These people were eager to follow the "proper rules" of polite society and often turned to etiquette manuals for information about those rules. ${ }^{3}$ Etiquette manuals served as a guide for correct behaviour and served to indoctrinate people into believing that their behaviour had to be proper in order to remain

\footnotetext{
1 Dan Azoulay, Hearts and Minds: Canadian Romance at the Dawn of the Modern Era, 1900-1930, (Calgary: University of Calgary Press, 2011): 94. ProQuest ebrary.

2 Azoulay, Hearts and Minds, 91.

${ }^{3}$ Azoulay, Hearts and Minds, 91.
} 
a respectable member of society. Furthermore, etiquette manuals warned of the dangers of living an immoral life: "Men who have no self-control, will find life a failure, both in a social and in a business sense. The world despises an insignificant person who lacks backbone and character." 4

An example of a Canadian etiquette book that stresses the value of a good reputation is Search Lights on Health, Light on Dark Corners: A Complete Sexual Science and a Guide to Purity and Physical Manhood, Advice to Maiden, Wife and Mother, Love, Courtship and Marriage, written in 1894 by B.G. Jefferis and J.L. Nichols. In this book, Jefferis and Nichols espouse the value of a good reputation. It could not be measured, but nothing stood in comparison to it and life had no meaning without it. ${ }^{5}$ It was believed that without a good reputation, people stood "despised, debased, [and] depreciated." 6 Not only that, but a person with a bad reputation would be "under eternal quarantine; no friend to greet; no home to harbor him."7 And once a good reputation was damaged there was no way to repair it. ${ }^{8}$

Reputation therefore was a crucial aspect of daily life. In order to establish a good reputation, people would need to associate with those people who had a good reputation. Jefferis and Nichols said, "the force of example is powerful; we are creatures of imitation, and, by a necessary influence, our tempers and habits are very much formed on the model of those with whom we familiarly associate." 9 If a person associated with someone who lacked principle, it was necessary to instantly shun them, so as not to be tainted by them. ${ }^{10}$ The good character of a male suitor was important so as not to degrade the woman's character or her family's character. And as Maude C. Cooke said in Social Etiquette or Manners and Customs of Polite Society, if a girl's suitor's character was flawed, she should

\footnotetext{
${ }^{4}$ B.G. Jefferis and J.L. Nichols, Search Lights on Health, Light on Dark Corners: A Complete Sexual Science and a Guide to Purity and Physical Manhood, Advice to Maiden, Wife and Mother, Love, Courtship and Marriage, (Toronto: J.L. Nichols Co., 1894), 16, Early Canadiana Online,

http://library.mtroyal.ca:5753/view/oocihm.29321

${ }^{5}$ Jefferis and Nichols, Search Lights on Health, Light on Dark Corners, 9.

6 Jefferis and Nichols, Search Lights on Health, Light on Dark Corners, 9.

7 Jefferis and Nichols, Search Lights on Health, Light on Dark Corners, 9.

8 Jefferis and Nichols, Search Lights on Health, Light on Dark Corners, 9.

9 Jefferis and Nichols, Search Lights on Health, Light on Dark Corners, 11.

${ }^{10}$ Jefferis and Nichols, Search Lights on Health, Light on Dark Corners, 12.
} 
not associate with him at all. ${ }^{11}$ For those families whose members did not live a moral life and gave into "impulses and passions" their family could not be happy and "would have been blighted forever."12 Therefore it was necessary to have behaviour controlled (either internally or externally) or for family to disown those members who transgressed.

In etiquette manuals, behaviour was classified in binary oppositions. Actions demonstrated either "honesty, or knavery; truth, or falsehood; of industry, or idleness ... self-denial, or self-indulgence."13 There was only one proper way to act, and if a person did not act in that way, they would be ostracized. Jefferis and Nichols believed that the desire for a good name (reputation) was an innate quality for those who wanted, and lived, a moral life; conversely, people who did not care for their reputation, lived an immoral life. ${ }^{14}$

The manual argued that when a man gave into impulses and passions, he gave up "his moral freedom." 15 In order "to be morally free-to be more than an animal-man must be able to resist instinctive impulse, and this can only be done by exercise of self-control."16 Self-control, or self-denial, was the opposite of self-indulgence. To live morally, people needed to suppress, and control, their "evil thoughts, evil passions, and evil practices."17 For men, suppressing these evil thoughts, passions, and practices, required them to abstain from sexual pleasures. Jefferis and Nichols wrote that "abstinence has been, and continues to be, liberty. Restraint is the noblest freedom. No man can affirm that self-denial ever injured him; on the contrary, self-restraint has been liberty, strength and blessing." 18 And because "manhood is morality and purity of purpose, not sensuality," a man must not give into prostitution, or even masturbation, but must wait for marriage. ${ }^{19}$

The language describing character, reputation, and morality in the manual is implicitly linked to sexuality; premarital sexuality is the antithesis of the social ideal the manual describes. Sexuality is described euphemistically, using words such as

\footnotetext{
11 Maude C. Cooke, Social Etiquette, or Manners and Customs of Polite Society, (London, Ontario: McDermid and Logan, 1896): 121, Internet Archive, https://archive.org/details/cihm 00092

12 Jefferis and Nichols, Search Lights on Health, Light on Dark Corners, 19.

13 Jefferis and Nichols, Search Lights on Health, Light on Dark Corners, 17.

14 Jefferis and Nichols, Search Lights on Health, Light on Dark Corners, 18.

15 Jefferis and Nichols, Search Lights on Health, Light on Dark Corners, 14.

16 Jefferis and Nichols, Search Lights on Health, Light on Dark Corners, 14.

17 Jefferis and Nichols, Search Lights on Health, Light on Dark Corners, 16.

18 Jefferis and Nichols, Search Lights on Health, Light on Dark Corners, 32.

19 Jefferis and Nichols, Search Lights on Health, Light on Dark Corners, 138.
} 
"temptations," "sensuality," "impulses and passions." These euphemisms are connected to being "immoral," "evil," and bring "shame, disease and death." ${ }^{20}$ Any public display of sexuality, would then seem certain to damage one's reputation, and be indicative of an immoral life.

In order to understand which public displays of sexuality were considered unacceptable, it is important to understand what behaviours were considered acceptable. Courtship rituals were aimed at maintaining the character, reputation, and morality of higher class citizens. As Peter Ward writes, "the principles of sexual segregation were aimed at keeping unrelated men and women apart, the young and unmarried in particular." ${ }^{21}$ Courtship rules stipulated that a man and woman should not give each other exclusive social attention and that a courting couple had to be chaperoned. These rules were designed to constrain pre-marital sex.

Courtship rituals demanded that men and women only show an appropriate amount of attention to one another. ${ }^{22}$ Attention placed wholly on one man or one woman was deemed unacceptable. Cooke cautions that "a true gentleman will never confine his attentions exclusively to one lady unless he has an intention of marriage," and that "a gentleman with no thought of marriage is honor bound to make his attentions to ladies as general as possible." ${ }^{23}$ Similarly, a woman was encouraged to have many suitors because it increased her chances of receiving a marriage proposal. ${ }^{24}$ At dances, women were encouraged not to dance with one person more than three times because it would be considered too forward and a woman had to display her attention equally to her suitors. ${ }^{25}$ Cooke's advice was mirrored elsewhere. The Prim Rose advice column-published in the Family Herald at the beginning of the twentieth century_suggested that, "it is not advisable to allow a young girl to be seen much in public with a friend of the other sex." 26 To place too much attention on one person would be to call attention to oneself and would cause

\footnotetext{
${ }^{20}$ Jefferis and Nichols, Search Lights on Health, Light on Dark Corners, 16, 19, 32.

${ }^{21}$ Peter Ward, Courtship, Love, and Marriage in Nineteenth-Century English Canada, (Montréal: McGill-Queen's University Press, 1990), 65. ProQuest ebrary.

22 Cooke, Social Etiquette, 122.

${ }^{23}$ Cooke, Social Etiquette, 122.

${ }^{24}$ Azoulay, Hearts and Minds, 95.

${ }^{25}$ Azoulay, Hearts and Minds, 97.

26 Prim Rose, 5 June 1907, 9, quoted in Azoulay, Hearts and Minds, 92.
} 
assumptions to be made about the couple's character. Assumptions about the couple's sexual behaviour would be made and it would damage their reputation. And even when a man and woman were engaged, they were still "more acquaintances than companions." ${ }^{27}$ Courting and engaged couples did not have the opportunity to get to know each other very well because of all the strictures placed on their behaviours. For engaged couples, "their [public] behaviour toward one another should not be markedly different from that displayed by them toward other men and women of their acquaintance."28 This shows how important it was for men and women to regulate their sexual behaviour in public.

Chaperons were instrumental for ensuring the preservation of reputations. A courting couple was usually chaperoned by a member of the young woman's family. ${ }^{29}$ Jefferis and Nichols recommended that "if a young lady desires to visit any public place where she expects to meet a gentleman acquaintance, she should have a chaperon to accompany her, a person of mature years when possible, and never a giddy girl. ${ }^{30}$ As Sangster points out, while both young men and young women had to monitor their reputations through their behaviour, "promiscuity was [seen as] essentially a female, not a male problem." 31 Therefore, the onus was on the female's family to prevent inappropriate sexual behaviours. Chaperons were important because they protected young women "from unscrupulous suitors making unwanted and inappropriate physical advances." ${ }^{32}$ They were also important because they prevented young women from acting inappropriately. ${ }^{33}$ This shows that young women were not trusted to regulate themselves and their passions. Another stricture that was placed on courting couples was that men were to call on women, but women were never to call on men because it would be a poor reflection of their character and taint their reputation. ${ }^{34} \mathrm{~A}$ woman could not go to a man's house without chaperon because it was believed that sexual acts would occur.

${ }^{27}$ Azoulay, Hearts and Minds, 125.

${ }^{28}$ Azoulay, Hearts and Minds, 133.

${ }^{29}$ Azoulay, Hearts and Minds, 99; Ward, Courtship, Love, and Marriage, 65-66.

30 Jefferis and Nichols, Search Lights on Health, Light on Dark Corners, 51.

${ }^{31}$ Joan Sangster, Girl Trouble: Female Delinquency in English Canada, (Toronto: Between the Lines, 2002): 34. ProQuest ebrary.

32 Azoulay, Hearts and Minds, 106.

${ }^{33}$ Azoulay, Hearts and Minds, 108.

${ }^{34}$ Azoulay, Hearts and Minds, 101. 
Etiquette manuals entreated men and women to be wary during their courtships. Men were encouraged to watch for woman who were too boisterous or flirtatious because that would insinuate a poor character. If a woman "should display a strong inclination towards affection and flirtation" a man can "conclude that very little home happiness is to be expected from her companionship." 35 If a woman was overly affectionate, it could be concluded that she was sexually promiscuous. Similarly, women were encouraged to remain reserved so as to maintain the respect of her suitor. ${ }^{36}$ As the etiquette manual, The Ladies Book of Useful Information, cautioned, "young men may like your free and hearty girls to laugh and talk with, but as to taking one for a wife, let me assure you they would not tolerate the idea for a moment." 37 Therefore, a woman had to act carefully so as not to detract from her character, for if her character was compromised, she could not find a man who would want to be her husband. In The Ladies Book of Useful Information women were further cautioned against pre-marital sexual activities:

No maiden can, under any circumstances, place her character in the hands of any man before marriage. No matter how sincere the love, how ardent the protestations, how earnest or plausible the pleadings, you must not, you cannot, surrender your honor. You must preserve your prudence and virtue. ${ }^{38}$

Again, it is evident that reputation is tied to sexual behaviours, and denying one's passions was essential to leading, a moral life.

Social class affected how applicable were proper courtship rituals. According to Ward, "the most rigid rules of propriety ... belonged to the social elite." 39 So while the middle and upper classes were concerned with their reputations and were therefore cognisant of the acceptable public displays of sexuality, working class people were not as concerned. For example, Azoulay writes that "the chaperon rule only applied ... to 'wellbred' women 'in good society' and not to 'girls of a common class'." 40 While lower class people could choose to chaperon a young couple, it was not always possible. Working

\footnotetext{
35 Cooke, Social Etiquette, 122.

36 The Ladies Book of Useful Information: Compiled From Many Sources, (London, Ont.: London Printing and Lithographing Co., 1896), 76. Early Canadiana Online. http://library.mtroyal.ca:5753/view/oocihm.08380

37 The Ladies Book of Useful Information, 82.

38 The Ladies Book of Useful Information, 76-77.

${ }^{39}$ Ward, Courtship, Love, and Marriage, 80.

${ }^{40}$ Azoulay, Hearts and Minds, 106.
} 
schedules did not always allow the time for people to chaperon. And as Dubinsky explains, courtship rituals did not "match the reality of working-class social life" because women and men had more frequent, and informal, interactions than men and women of higher classes. ${ }^{41}$

Nevertheless, people in lower classes regulated sexual behaviour too but in different ways. Despite not typically employing a chaperon system, lower class people still had to be careful of overt sexual behaviour. In lower class families, a young girl's fear of punishment from her family-her father in particular-would often be used as a deterrent or regulating factor for sexual behaviour..$^{42}$ The regulation of sexuality for lower class people was based on the fear of punishment, but it was also based on the fear of losing one's reputation, and the reputation of the family. ${ }^{43}$ The family was tied to the morality of their daughters. As Dubinsky writes "the family, far more than church and state, was charged with the task of 'creating self-regulating sexual beings'." 44 Thus, for both lower and upper classes, sexuality was meant to be self-regulated. Dubinsky observes, "certain sexual standards became hegemonic and internalized, part of everyday life." 45 Etiquette manuals reified the internalization of self-regulation by espousing what were considered to be acceptable public displays of sexual behaviours and contrasting them with what were considered to be unacceptable behaviours.

Community watchfulness was another important mode of regulating public displays of sexuality. ${ }^{46}$ Family, neighbors, and even strangers could criticise or comment on immoral behaviour. As Dubinsky said, "strangers often noted and acted upon behavior they deemed morally suspect." 47 This notion of community watchfulness can be seen in Schmidt's example of a park ranger in Montreal's Mount Royal Park who observed "a gentleman sitting on a bench with his arms around a lady's waist. Concluding that this behaviour

\footnotetext{
${ }^{41}$ Karen Dubinsky, Improper Advances: Rape and Heterosexual Conflict in Ontario, 1880-1929, (Chicago: The University of Chicago Press, 1993): 117.

${ }^{42}$ Dubinsky, Improper Advances, 120-121.

${ }^{43}$ Dubinsky, Improper Advances, 120.

${ }^{44}$ Dubinsky, Improper Advances, 121.

45 Dubinsky, Improper Advances, 112.

46 Dubinsky, Improper Advances, 122-123.

47 Dubinsky, Improper Advances, 123.
} 
transgressed society's informal 'sex' rules, he ordered the man to remove his hands." 48 It was important for couples to know the informal sex rules and display proper sexual behaviour in order to avoid harassment. ${ }^{49}$ Even though the couple in the park were married, it was deemed unacceptable by the park ranger. However, there was backlash against the ranger's protest of the couple which might indicate that the larger public opinion did not believe that a husband's arm around his wife was unacceptable.

As urban centers grew at the beginning of the twentieth century, societal norms were tested in three ways: communities were growing larger therefore offering more social opportunities, women were entering the workforce and gaining independence, and more commercial amusements were being created. Like reputation, character, and morality, these factors of urbanization were interrelated and are important to the understanding of public displays of sexuality. As these factors emerged, more and more of the acceptable displays of heterosexuality were challenged.

Rapid urbanization occurred at the end of the nineteenth century and into the twentieth century. For instance, Toronto was becoming a large urban center and by 1911 its population was one-third of a million. ${ }^{50}$ Even by 1900 , as the nation grew and as urbanization occurred, the "character of social groups and social relationships changed," which created "new freedoms and new restraints for all of those who courted." ${ }^{11}$ Changing social relationships were created as public spaces became "hetero-social" and anxieties about "the eroticization of public space" emerged. ${ }^{52} \mathrm{New}$ freedoms included the ability for young people to leave the home for "economic, educational or recreational activities." 53 These new freedoms and restraints caused anxieties about the morality of society. Urban centers were beginning to be seen as harbouring social evils like "poverty, disease, crime, and immorality." ${ }^{4}$ Part of these social evils included "sexual danger[s], [and]

\footnotetext{
${ }^{48}$ Sarah Schmidt, "Private Acts' in 'Public' Spaces: Parks in Turn-of-the- Century Montreal" In Power, Place and Identity, ed. Tamara Myers et al. (Montreal: Montreal History Group, 1996): 142.

${ }^{49}$ Schmidt, "'Private Acts' in 'Public' Spaces," 142.

${ }^{50}$ Carolyn Strange, Toronto's Girl Problem: The Perils and Pleasures of the City, 1880-1930, (Toronto:

University of Toronto Press, 1995), 37.

51 Ward, Courtship, Love, and Marriage, 71.

52 Alan Hunt, "Regulating Space: Sexual Politics in the Early Twentieth Century," Journal of Historical Sociology 15, no. 1 (2002): 15. Wiley-Blackwell.

${ }^{53}$ Hunt, "Regulating Space," 8.

54 Hunt, "Regulating Space," 13.
} 
commercialized vice."55 The social evils of immorality, sexual danger, and commercialized vice were all centered around what were considered to be unacceptable public displays of sexuality.

Anxieties about public displays of sexuality were bolstered by women who gained independence outside of the home and in the workforce. ${ }^{56} \mathrm{As}$ an example of the increase in female labour, in Toronto, the female labour force went from "approximately 6,400 wage earners in 1881 to more than 42,000 by $1911 . " 57$ Women who worked outside of the home had the opportunity to meet new people, gain some independence, and experience a different life than they were used to. ${ }^{58}$ Society was used to women's roles as mothers and wives, not as workers. ${ }^{59}$ The construction of women as wives had cultural implications in that it emphasized what female sexuality was and was not, subsequently restricting the parameters of what sexual behaviour was acceptable. ${ }^{60}$ Their contribution outside of the home therefore was a cause for concern. It was believed that working women provided a threat to the "moral stability of the nation." ${ }^{11} \mathrm{~A}$ woman's morality was affected by her character which was supposed to be created by her refined sexuality as a wife and mother. For those women who delayed marriage, their morality was questioned.

Anxieties were also enhanced by the spread of commercialized amusements. As the 1915 Toronto Social Survey Report stated, public sites like dance halls, skating rinks, and amusement parks were just some of the places that harboured vice. ${ }^{62}$ It was believed that these unregulated public spaces produced immoral activities. The increase in the degree of contact between men and women subsequently tested the behaviours that were considered acceptable. As Hunt pointed out, "commercialized leisure and recreation facilitated heterosexual familiarity." ${ }^{33}$ And women in the early twentieth century experienced an "unprecedented degree of social autonomy and anonymity" compared to

55 Dubinsky, Improper Advances, 115.

${ }^{56}$ Dubinsky, Improper Advances, 115-116.

${ }^{57}$ Strange, Toronto's Girl Problem, 37.

58 Dubinsky, Improper Advances, 116.

${ }^{59}$ Sarah Carter, The Importance of Being Monogamous: Marriage and Nation Building in Western Canada to 1915, (Edmonton: The University of Alberta Press, 2008), 25; Strange, Toronto's Girl Problem, 27.

${ }^{60}$ Carter, The Importance of Being Monogamous, 25.

61 Strange, Toronto's Girl Problem, 27.

${ }^{62}$ Report of the Social Survey Commission Toronto: Presented to the City Council, October 4th, 1915. Toronto: The Carswell Company, 1915, 50-51, http://hdl.handle.net/2027/hvd.32044011640679

${ }^{63}$ Hunt, "Regulating Space," 17. 
the prior century, which allowed them to associate more freely with men. ${ }^{64}$ In the Toronto Social Survey Report, public life was seen as having an "unfavorable moral atmosphere" because of "the free and promiscuous intercourse of the sexes in public dances, the readiness with which young girls enter into conversation with strangers at public rinks, and make free with young men to whom they have not been introduced." ${ }^{65}$ Acceptable public norms were tested and began to break down.

As alluded to, the courtship model was tested as commercial amusements emerged. ${ }^{66} \mathrm{As}$ spaces became more urbanized and as social barriers were tested, acceptable sexual behaviours were similarly tested. One of the behaviours that was tested were courtship rituals. Ward gave examples of young men who began to break the courtship rules and fraternize with women in traditionally unacceptable ways. ${ }^{67}$ For instance, etiquette required that introductions to strangers be made through an intermediary, so that when a young man wanted to meet a young woman, a mutual acquaintance would be required to introduce them. But Ward gave the example of Kelso, a young man who would not adhere to the etiquette of introduction and would introduce himself to any young woman at any time. ${ }^{68}$ As appropriate social behaviours like courtship rituals were tested, anxieties were created about the morality of the community.

These anxieties can be seen in the Toronto Social Survey Report and other similar reports done across Canada and the United States. The Toronto Social Survey Commission was created on October $27^{\text {th }} 1913$ to study social vice within the city. ${ }^{69}$ The Social Survey Report looks at certain conditions that were related to the "social evil," including houses of ill-fame, individual prostitutes, street soliciting and occasional or semi-professional prostitution, to name a few. For the purposes of this paper, "occasional prostitutes" were the most important "vice" studied. The "occasional prostitute" is "a woman or girl who, while living an immoral life, does not depend for her living wholly upon the proceeds of prostitution"; rather, she "follows some other vocation, but supplements her income by

\footnotetext{
${ }^{64}$ Dubinsky, Improper Advances, 115.

${ }^{65}$ Report of the Social Survey Commission Toronto, 56.

66 Dubinsky, Improper Advances, 16.

67 Ward, Courtship, Love, and Marriage, 78-79.

${ }^{68}$ Ward, Courtship, Love, and Marriage, 78-79.

${ }^{69}$ Report of the Social Survey Commission Toronto, 7.
} 
prostitution."70 Many of these "occasional prostitutes" were undoubtedly prostitutes, but just as many were likely not. Instead, social anxieties, created by the new public heterosocial environment and the heterosexual familiarity, were explained and understood as "occasional prostitution," when in fact it was the emergence of an "early dating culture."

As young women entered the work force, and commercialized amusements emerged, the courtship model started to wane and a new one started to be created. Hunt calls this transition period "a new stage of hetero-social relations." ${ }^{71}$ These new forms of courtship were not "named as 'dating' until the 1920s." 72 However, they did resemble dating, and because of this, these new forms can be called "early dating." The characteristics of the early dating culture can be seen in the Toronto Social Survey Report when it talks about "occasional prostitutes." "Occasional prostitutes" were seen as doing it "'for fun' or 'for a good time'."73 Many did not get paid; rather, they did it for the company of the man, or for "the suppers, shows and drinks" that they got. ${ }^{74}$ Some were given "presents of jewelry, clothing" and other gifts. ${ }^{75}$ And many went to "restaurants, hotels, theatres, dance halls, rinks, [and] picture shows ... to 'pick up' men."76 These descriptions sound like an early dating culture, not like prostitution.

Commercial amusements were places where these new "dates" occurred. Dance halls, skating rinks, and amusement parks were just some of the locations where men and women could go. ${ }^{77}$ Dance halls in Toronto were considered to be problematic because "there was no supervision, and the practice of men accosting and dancing with girls whom they did not know was general." ${ }^{78}$ Dancing was considered to be a sexually charged activity which was another concern for the social surveyors. ${ }^{79}$ The problems of no supervision, and of men accosting women, were also seen in skating rinks which were found to be "used as

\footnotetext{
${ }^{70}$ Report of the Social Survey Commission Toronto, 12.

${ }^{71}$ Hunt, "Regulating Space," 17.

72 Hunt, "Regulating Space," 17.

${ }^{73}$ Report of the Social Survey Commission Toronto, 12.

${ }^{74}$ Report of the Social Survey Commission Toronto, 12.

75 Report of the Social Survey Commission Toronto, 12.

${ }^{76}$ Report of the Social Survey Commission Toronto, 13.

${ }_{77}$ Report of the Social Survey Commission Toronto, 50-51.

${ }_{78}$ Report of the Social Survey Commission Toronto, 50.

${ }^{79}$ Hunt, "Regulating Space," 18.
} 
rendezvous for immoral purposes" and promiscuous behaviour. ${ }^{80}$ At amusement parks, the immoral behaviour took the form of "picking up," which was characterized as men paying for women at the fair booths. ${ }^{81}$ These "occasional prostitutes" were considered dangerous because they could appear outwardly respectable and "the innocent or pure-minded of either sex may have to be in daily and hourly association with the corrupt." 82 Therefore, fear for the morality of the community was central to the discussions about "occasional prostitutes."

The descriptions of these "dates" were highly sexualized and because of their interactions with men, these "occasional prostitutes" were considered to be morally depraved. Furthermore, it was believed that men and women were not behaving properly because they were not courting with chaperons. This new dating culture was so drastically different from the courtship model that social surveyors were used to that they could not comprehend what was happening. Thus, the women who engaged in the early dating culture were called "occasional prostitutes" because it was the only way that the surveyors could rationalize what was occurring. Especially since these surveyors lived in a culture that judged character in binary oppositions, these women were labelled as either chaste or prostitutes, who behaved acceptably or unacceptably.

The societal norms that were prominent in the nineteenth century regarding public displays of sexuality started to change at the turn of the century as urbanization tested the morals of the community. Because character was judged in extremes, a person was either moral or immoral, chaste or corrupted, sexual or abstinent. These strict categories did not allow for variation and when women started to gain independence, their morality, and the flaws in their morality, were seen as degrading the community. As commercial amusements arose, women and men took advantage of them and started to break the courtship model. Women who did this were labelled as "occasional prostitutes" because social surveyors could not make sense of the new social environment that was being created. Instead of being "occasional prostitutes," women were engaging in an early dating culture where men and women went to public places unchaperoned. By doing this, men and women were

\footnotetext{
80 Report of the Social Survey Commission Toronto, 50-51.

81 Report of the Social Survey Commission Toronto, 51.

82 Report of the Social Survey Commission Toronto, 13.
} 
breaking down the strict regulations set forth in etiquette manuals that espoused acceptable behaviours. In fact, men and women were engaged in unacceptable behaviours that the etiquette manuals warned against. This new social environment disregarded the emphasis on reputation, character, and morality, and actively created new societal norms. As Hunt concludes, "activities that had earlier been regarded as unacceptable came to be acceptable and normalized." ${ }^{83}$ As societal norms were tested by the effects of urbanization, an early dating culture emerged that created new ideas about what was considered acceptable public display of sexual behaviour.

${ }^{83}$ Hunt, "Regulating Space," 5. 


\section{Works Cited}

Primary Sources

Cooke, Maud C. Social Etiquette or Manners and Customs of Polite Society. London, Ontario: McDermid and Logan, 1896. Internet Archive. https://archive.org/details/cihm_00092

Jefferis, B.G. and J.L. Nichols. Search Lights on Health, Light on Dark Corners: A Complete Sexual Science and a Guide to Purity and Physical Manhood, Advice to Maiden, Wife and Mother, Love, Courtship and Marriage. Toronto: J.L. Nichols Co., 1894. Early Canadiana Online. http://library.mtroyal.ca:5753/view/oocihm.29321

Report of the Social Survey Commission Toronto: Presented to the City Council, October 4th, 1915. Toronto: The Carswell Company, 1915. http://hdl.handle.net/2027/hvd.32044011640679

The Ladies Book of Useful Information: Compiled From Many Sources. London, Ont.: London Printing and Lithographing Co., 1896. Early Canadiana Online. http://library.mtroyal.ca:5753/view/oocihm.08380

Secondary Sources

Azoulay, Dan. Hearts and Minds: Canadian Romance at the Dawn of the Modern Era, 19001930. Calgary: University of Calgary Press, 2011. ProQuest ebrary.

Carter, Sarah. The Importance of Being Monogamous: Marriage and Nation Building in Western Canada to 1915. Edmonton: The University of Alberta Press, 2008.

Dubinsky, Karen. Improper Advances: Rape and Heterosexual Conflict in Ontario, 1880-1929. Chicago: The University of Chicago Press, 1993.

Hunt, Alan. "Regulating Space: Sexual Politics in the Early Twentieth Century." Journal of Historical Sociology 15, no. 1 (2002) 1-34. Wiley-Blackwell.

Sangster, Joan. Girl Trouble: Female Delinquency in English Canada. Toronto: Between the Lines, 2002. ProQuest ebrary. 
Schmidt, Sarah. "Private Acts' in 'Public' Spaces: Parks in Turn-of-the- Century Montreal." In Power, Place and Identity, edited by Tamara Myers et al, 130-49. Montreal: Montreal History Group, 1996.

Strange, Carolyn. Toronto's Girl Problem: The Perils and Pleasures of the City, 1880-1930. Toronto: University of Toronto Press, 1995.

Ward, Peter. Courtship, Love, and Marriage in Nineteenth-Century English Canada. Montréal: McGill-Queen's University Press, 1990. ProQuest ebrary. 